\title{
Analysis of Judges' Considerations in Deciding Judicial Divorce at the Palu Religious Court
}

\author{
Alhamid Baharuddin ${ }^{1 *}$,M. Taufan B ${ }^{2}$, Syahabuddin Syahabuddin ${ }^{3}$ \\ ${ }^{1}$ Islamic Family Law Department, Postgraduate, Institut Agama Islam Negeri Palu \\ ${ }^{2}$ Islamic Family Law Department, Postgraduate, Institut Agama Islam Negeri Palu \\ ${ }^{3}$ Islamic Family Law Department, Postgraduate, Institut Agama Islam Negeri Palu
}

\begin{abstract}
The aim of this paper is to discuss Judges' consideration in making decision in the case of judicial divorce. This study uses qualitative methods and data was gathered through observation, in-depth interviews, and written material. Data analysis was analyzed using grounded theory approach. The results showed that there were two basic considerations for judges in deciding a lawsuit for divorce at the Palu Religious Court Class 1A, namely written law and unwritten law. Written laws include Al-Qur'an, Hadith, Laws, and Compilation of Islamic Laws, while the unwritten law is the customs and values that live in society. Based on the decision Number 452/Pdt.G/2019/PA.Pal, these laws were used as the basis for the judge's consideration in deciding this case, because continual disputes and quarrels occurred between husband and wife, that resulted to the separation of residence which has lasted for about 11 months, and it is no longer possible to live in harmony in the household.
\end{abstract}

ARTICLE

INFORMATION

Keywords:

Judges consideration, divorce suit, religious court, Palu 


\section{Introduction}

Basically, divorce is legalized according to the arguments of the Qur'an and the Hadith of the Prophet Muhammad; however divorce is hated by Allah. In this case, it is not the divorce that is hated, but the causes leading to the divorce, such as a bad relationship between husband and wife and the disputes that occur between the two. ${ }^{1}$

Because frequent disputes in the family are caused by differences in character and desires between husband and wife, which lead to divorce, a legal institution is needed to handle the divorce. ${ }^{2}$ With the help of this legal institution, divorce will not be carried out arbitrarily. What is meant by legal institution here is the Religious Court.

The Religious Court is a legal institution that has the task to examine, decide and settle the cases among Muslims at the first level in the fields of marriage, inheritance, wills, grants, waqf, zakat, infaq, shadaqah and shari'ah economics. This is regulated in the article 49, Law Number 3 of 2006 concerning Reform of Law Number 7 of 1989 concerning Religious Courts. ${ }^{3}$

The Republic of Indonesia has regulated the procedures and processes for divorce through Law Number 1 of

${ }^{1}$ Rusli Rusli, "Hermeneutical Reading of Țalāq," HUNAFA: Jurnal Studia Islamika 12, no. 2 (2016): 209-229.

2 Rusli Rusli, "The Role of Family in Preventing Social Conflict in Society From Islamic Perspectives," HUNAFA: Jurnal Studia Islamika 17, no. 1 (2020): 108-122.

3Undang-Undang Nomor 3 Tahun 2006 Tentang Pembaharuan Atas Undang-Undang Nomor 7 Tahun 1989 Tentang Peradilan Agama.
1974 concerning Marriage. In chapter IV, there are several articles that regulate the cancellation of marriage, including Article 25 which states:

An application for the cancellation of marriage is submitted to the Court in the jurisdiction where the marriage took place or in the both husband and wife's residence, husband and wife. ${ }^{4}$

As in Chapter VI, it is stated that if the husband and wife do not exercise their rights and obligations, then it applies to both. It is stated in Article 34 paragraph 3, "If the husband or wife neglects their respective obligations, they can file a lawsuit to the Court." 5

To explain the Law Number 1 of 1974 concerning Marriage, the Republic of Indonesia Government Regulation Number 9 of 1975 concerning Implementation of Law Number 1 of 1974 concerning Marriage was issued. Among these is Chapter V on Divorce Procedures, Article 14:

"A husband who is married according to the Islamic religion, who is going to divorce his wife, submits a letter to the Court at his residence, which states that he intends to divorce his wife along with his reasons and asks the Court to hold a hearing for this purpose."6

${ }^{4}$ Undang-Undang Republik Indonesia No. 1 Tahun 1974 Tentang Perkawian, Bab IV Pasal 25 (Jakarta: Raja Grafindo Pers, 2002), 155.

5Ibid, 158.

6Peraturan Pemerintah Republik Indonesia Nomor 9 Tahun 1975 Tentang Pelaksanaan Undang-Undang Nomor 1 Tahun e-ISSN: $2715-4580$ p-ISSN: 2715-8268 
Divorce committed by Muslims can only be carried out before a Religious Court hearing, as confirmed in Presidential Instruction No. 1 of 1991 concerning Compilation of Islamic Law (KHI) Article 115.

Divorce being carried out before a court hearing aims to prevent a divorce that is carried out without consideration and reasons justified by law, or to prevent the husband who has the right to divorce from exercising his right arbitrarily.

In deciding cases, the most important thing is the legal conclusion on the facts revealed at the trial. For that, judges must explore and understand the legal values and a sense of justice living in society. ${ }^{7}$ Sources of law that can be applied by judges can be in the form of statutory regulations and their implementing regulations, unwritten law (customary law), village decisions, jurisprudence, science and doctrine of experts. Legal considerations made by a judge can be based on philosophical, juridical, sociological aspects, which reflect the principles of legal certainty, justice and benefit for the parties. ${ }^{8}$

The Supreme Court has determined that the judge's decision must consider several aspects that are juridical, philosophical, and sociological,

1974 Tentang Perkawian, BAB V (Jakarta: Raja Grafindo Pers, 2002), 183.

${ }^{7}$ Rusli, R. (2017). Wahdah Islamiyyah Palu: on Contemporary Islamic Legal Issues in The Internet. Hunafa: Jurnal Studia Islamika, 14(2).

${ }^{8}$ Nur Iftitah Isnantiana, Legal Reasoning Hakim Dalam Pengambilan Putusan Perkara di Pengadilan,Jurnal Pemikiran Islam ISLAMADINA 18, no. 2 Juni (2017): 54. so that the justice that is achieved, realized and accounted for in the judge's decision is justice oriented towards legal justice, moral justice, and social justice. ${ }^{9}$

The juridical aspect is the main aspect that is based on the applicable law. Judges as a law implementer must understand the law by looking for laws related to the case at hand. The judge must assess whether the law is fair, useful, or provides legal certainty if it is enforced. Because one of the elements of law is to create justice.

The philosophical aspect is an aspect that has the essence of truth and justice, while the sociological aspect considers the cultural values that live in society. In its application, philosophical and sociological aspects really require extensive experience and knowledge and wisdom that are able to follow the values in a neglected society. It is clear that the implementation is very difficult, because it does not follow the legal principle and is not related to the system. The inclusion of these three elements is none other than so that the decision is considered fair and accepted by the community

\section{Literature Review}

\subsection{Decision Theory}

${ }^{9}$ Mahmakah Agung Republik Indonesia, Pedoman Perilaku Hakim (Code of Conduct), Kode Etik Hakim (Jakarta: Pusdiklat MA RI, 2006), 2; Sukaenah Sukaenah, Rusli Rusli, and M. Taufan B, "The Effectiveness of Indonesia Supreme Court Regulation Number 1 Year 2016 Concerning Mediation of Marriage Disputes," INTERNATIONAL JOURNAL OF CONTEMPORARY ISLAMIC LAW AND SOCIETY 2, no. 1 (2020): 63-80.

e-ISSN: 2715-4580 p-ISSN: 2715-8268 
In deciding a decision, according to Mackenzie, there are several theories or approaches that can be used by judges in considering a decision in a case. ${ }^{10}$

a. Teori of Balance

What is meant by balance here is the balance between the requirements determined by law and the interests of the parties involved in or related to the case.

\section{b. Intuition Theory}

Institutional theory posits that a decision made in an organization is determined by all elements within the organization. ${ }^{11}, 12$ Imposing a decision by a judge is at the judge's discretion or authority. As discretion, in making a verdict, the judge will adjust to the circumstances and a reasonable sentence for each perpetrator of a criminal act or in a civil case. The judge will look at the situation of both parties in the case, namely the plaintiff and defendant in a civil case, or the defendant and public prosecutor in a criminal case. Imposing the verdict, the judge uses an artistic approach, which is more determined by

\footnotetext{
10Rifai, Penemuan, 102.

11 Nurdin, N. (2018). Institutional Arrangements in E-Government Implementation and Use: A Case Study From Indonesian Local Government. International Journal of Electronic Government Research (IJEGR), 14(2), 44-63. https://doi.org/10.4018/ijegr.2018040104

12 Nurdin, N., Stockdale, R., \& Scheepers, H. (2014a). Coordination and Cooperation in EGovernment: An Indonesian Local E-Government Case The Electronic Journal of Information Systems in developing Countries, 61(3), 1-21.
}

instinct or intuition than by the knowledge of the judge. ${ }^{13}$

c. Theory of Scientific Approach

The starting point of this science is the idea that the criminal imposition process must be carried out systematically and with great care, especially in relation to previous decisions in order to ensure the consistency of judges' decisions.

\section{d. Theory of Experience Approach}

The experience of a judge is something that can help him in dealing with the cases he faces daily.

\section{e. Theory of Ratio Decindendi}

This theory is based on a fundamental philosophical foundation that considers all aspects related to the subject matter of the disputed case, then looks for the laws and regulations relevant to the subject matter in dispute as a legal basis for making decisions, and judges' considerations must be based on clear motivations to enforce the law, and provide justice for the parties in litigation.

\section{f. Theory of Wisdom}

This theory emphasizes that the government, society, family and parents are responsible for guiding, fostering, educating and protecting the accused, so that one day he can become a useful human being for his family, society and nation. ${ }^{14}$

\footnotetext{
13Ibid., 102.

14bid., 102.
} 


\subsection{Stages of Judge's Duty}

It must be realized by judges that law is not an exact matrix but social science, so it must be constructed logically, argumentatively, and rationally, when judges examine and adjudicate cases in order to produce a fair decision, which has legal certainty and is useful.

\subsection{Cerai gugat (judicial divorce)}

Judicial divorce is the breaking of the marriage bond as a result of a request submitted by the wife to the Religious Court, which then the respondent (husband) agrees, so the religious court grants the request. 15

According to Subekti, the term divorce is the abolition of a marriage by a judge's decision, or a claim by one of the parties in the marriage. ${ }^{16}$ In the Compilation of Islamic Law, Article 114 states that the dissolution of a marriage is caused by divorce or divorce suit from wife. ${ }^{17}$

According to the Law No. 7/1989 on the Religious Courts, the term used for divorce applications is called "Cerai Talak" (talaq divorce), while for divorce suit, the term becomes "Cerai Gugat" (judial divorce). ${ }^{18}$ With this new

${ }^{15} \mathrm{H}$. Zainuddin Ali, Hukum Perdata Islam di Indonesia, (Jakarta: Sinar Grafika, 2009), 81.

16Subekti, Pokok-Pokok Hukum Perdata, (Cet. XXXI: Jakarta: PT. Intermasa, 2003), 42.

17Tim Redaksi FOKUSMEDIA, Himpunan Peraturan Perundang-Undangan Tentang Kompilasi Hukum Islam, (Bandung: Fokusmedia, 2005), 38.

18Yahya Harahap, Kedudukan Kewenangan Dan Acara Pengadilan Agama, (Cet. Ke-2: Jakarta: Sinar Grafika, 2003), 207. term, the form of marriage breakdown is emphasized based on the decision of the Religious Court in accordance with Islamic Law. ${ }^{19}$

Ahrum Hoerudin also defined cerai gugat as a lawsuit filed by the plaintiff (wife) to the Religious Court, so that the marriage bond between herself and her husband is untied by a decision from the Religious Court, in accordance with the applicable legal regulations. ${ }^{20}$

It is also explained in The Compilation of Islamic Law, Article 132 Paragraph 1 that:

"A divorce suit is filed by the wife or her attorney at the Religious Court whose jurisdiction includes the Plaintiff's residence unless the wife leaves the joint residence without the husband's permission" ${ }^{21}$

In Islamic law, it is explained that the case in which the wife asks her husband to divorce her is called khulu'

${ }^{19}$ Muslih, I., Nurdin, N., \& Marzuki, M. (2020). Effectiveness of Marriage Services Through Information System Management (SIMKAH) at Palu City Religious Court INTERNATIONAL JOURNAL OF CONTEMPORARY ISLAMIC LAW AND SOCIETY, 2(1), 20-36.

${ }^{20}$ Ahrum Hoerudin, Pengadilan Agama (Bahasan Tentang Pengertian, Pengajuan Perkara, dan Kewenangan Pengadilan Agama Setelah Berlakunya Undang-Undang Nomor 7 Tahun 1989 Tentang Peradilan Agama), (Bandung: PT. Aditya Bakti, 1999), 20.

21Undang-Undang RI No. 1 Thaun 1974 Tentang Perkawinan dan Kompilasi Hukum Islam Serta Perpu Tahun 2009 Tentang Penyelenggaraan Ibadah haji, (Surabaya: Kesindo Utama, 2012), 235. 
(خ). A break in the marriage relationship between husband and wife is equated with removing clothes as the Qur'an states that the wife is a cloth for a husband, and vice versa, a husband becomes a cloth for a wife. ${ }^{22}$

\section{Methodology}

This study uses qualitative approach $^{23}$ investigating Judges' Considerations in Deciding Divorce Suit at the Palu Religious Court. The informants of this study are the head of the Palu city court, five judges, and the clerk of the court.

Data were collected through observations, in-depth interviews and shared written documents. Data analysis consists of several procedures: reduction and verification techniques with various data sources. ${ }^{24},{ }^{25}$ The reduced data is then analyzed reflecting on theoretical concepts used in this study. ${ }^{26,27}$

${ }^{22}$ Amir Syarifuddin, Hukum Perkawinan Islam di Indonesia (Antara Fiqih Munakahat dan UU Perkawinan), (Jakarta: Prenada Media, 2007), 231.

${ }^{23}$ Nurdin, N., \& Yusuf, K. (2020).

Knowledge management lifecycle in Islamic bank: the case of syariah banks in Indonesia. International Journal of Knowledge Management Studies, 11(1), 59-80.

https://doi.org/10.1504/ijkms.2020.105073

24 Nurdin, N. (2017a). Research in Online Space: The Use of Social Media for Research Setting Jurnal Sistem Informasi (Journal of Information System), 13(1), 67-77.

${ }^{25}$ Nurdin, N. (2017b). To Research Online or Not to Research Online: Using Internet-Based Research in Islamic Studies Context. Indonesian Journal of Islam and Muslim Societies, 7(1), 31-54.

26 Nurdin, N., \& Yusuf, K. (2020). Knowledge management lifecycle in Islamic bank: the case of syariah banks in Indonesia. International Journal of Knowledge Management

\section{Result and Discussion}

\subsection{Factors of judicial divorce}

To find out the factors that became the reasons for judicial divorce case in the Palu Religious Court Class 1.A, observation and interviews were carried out. Based on the interview with Muwafiqoh, $\mathrm{SH}$., $\mathrm{MH}$, one of the judges in Religious Court Palu, the reasons for judicial divorce varied, that include adultery, drunkenness, drugs, gambling, and leaving a wife or husband. ${ }^{28}$

\subsection{Judges' Basis for consideration in deciding judicial divorce case}

Judicial divorce is one of the cases handled by the Palu Religious Court Class 1.A. In 2019, there were 633 cases of divorce lawsuits filed at this court. There were 765 cases that were received by the Palu Religious Court from January to December 2019, including the remaining 63 cases in 2018 and 702 cases received in 2019. Of the 765 cases for divorce, 78 cases were withdrawn by the plaintiffs, 4 were rejected, 14 were not accepted, 10 were invalidated, 3 were crossed out and 633 were granted. Meanwhile, two

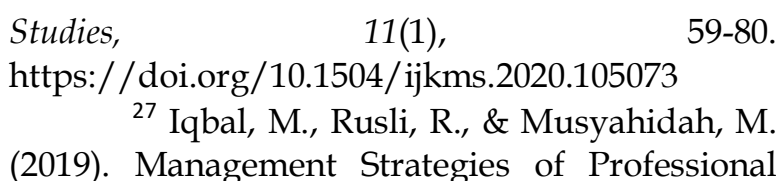
Zakat Funds for Mustahiq Family Welfare By Amil Zakat Body INTERNATIONAL JOURNAL OF CONTEMPORARY ISLAMIC LAW AND SOCIETY, 1(1), 39-51.

${ }^{28}$ Muwafiqoh, judge of Religious Court, Class 1.A, Interview, Palu, 22 June 2020.

e-ISSN: $2715-4580$ p-ISSN: 2715-8268 
judicial divorce cases were filed for appeal in 2019.29

Divorce cases received by the Palu Religious Court Class 1.A from January to June 2020 are 320 cases, including 63 talaq divorce cases, 257 judical divorce cases; 1 case removed from the register; 3 cases rejected; 4 cases were unaccepted, and 10 cases were dropped. ${ }^{30}$

If the plaintiff is deemed unsuccessful in proving the argument for his claim, the legal consequence that he must bear because of failure to prove the argument for his claim is that his claim must be completely rejected. Therefore, if a lawsuit cannot be proven by the argument that the defendant deserves to be punished for doing violation stated in the lawsuit, then the lawsuit will be rejected. Case is revoked; it means that they do not submit the petition because they have reconciled or the mediator has succeeded in reconciling. The petitioner never appeared in court, even though he had been summoned legally and properly. In Article 148 R.Bg, legal means that the summons are conveyed to the person concerned or if the person concerned is not found, then it is submitted to the Head of Village or his secretary. Proper means that the summons must be delivered three working days before the trial is held. ${ }^{31}$

Therefore, based on Article 148 R.Bg, which reads, "In the first trial, the plaintiff was not present at the trial, 2020.

29Source: Religious Court Palu Class I A,

${ }^{30}$ Source: Religious Court Palu Class I A,

2020.

31Source: Religious Court Palu, Class 1.A, while the defendant was present at the trial, the Judge, in this circumstance, could issue a verdict by declaring that the plaintiff's lawsuit was null and void and punished the plaintiff to pay court fees".

Certainly, before the judge makes a verdict on a case, especially in a case of divorce lawsuit, the plaintiff or applicant will first go through several processes, such as registration and case examination. A judge in conducting case examinations refers to Law Number 7 of 1989 which has been renewed by Law Number 3 of 2016 and Law Number 50 of 2009. This is stated by one of the judges of the Palu Religious Court 1.A class. ${ }^{32}$

After registration, the case will go to the chairman, where he or she will determine who the judges will handle the case, including mediator, clerk, substitute clerk, appoints the panel of judges who which will stipulate the session day for the case being handled, as conveyed by Mrs. Dra. Tumisah. ${ }^{33}$

After the case is submitted and it arrives on the day of the trial, the rules for each case that are resolved will apply. If both parties are present, then peace efforts must be made. The basis is Article 154 R.Bg.

In the process of trial for divorce cases, if the efforts have been made to

32Tumisah, Judge of Religious Court, Class 1.A, Interview, Palu, 04 May 2020.

${ }^{33}$ Tumisah, Judge of Religious Court, Class 1.A, Interview, Palu, 04 May 2020. 
reconcile the two parties by the panel of judges and in the mediation process by the mediator, the provisions of Article 82 paragraph (1) and (4) of Law Number 7 of 1989 as amended by Law Number 3 of 2006 and Law Number 50 of 2009 in conjunction with Article 154 paragraph (1) R.Bg and Article 2 of Regulation of the Supreme Court of the Republic of Indonesia Number 01 of 2008 as amended by Regulation of the Supreme Court of the Republic of Indonesia Number 01 of 2016 regarding Mediation Procedures in Courts, have been implemented.

However, if the efforts of reconciliation are not successful, the subject matter is examined in a closed session to the public. This is in accordance with the provisions of Article 80 paragraph (2) of Law Number 7 of 1989, as amended by Law Number 3 of 2006 and Law Number 50 of 2009.

The contentious case is if during the trial the two parties come, then the peace effort is directed to mediation, the basis of which is PERMA Number $1 / 2016$. If the mediation process is successful, then the case will not be continued, then the case will be withdrawn, as described by a judge, Mrs. Muwafiqoh. ${ }^{34}$ However, if the mediation efforts that are taken are not successful, the panel of judges will continue the case, to the level of case examination. ${ }^{35}$

One form of consideration that a judge makes in making a decision after a

\footnotetext{
${ }^{34}$ Muwafiqoh, Judge of Religious Court Palu, Class 1.A, Interview, Palu, 22 Juni 2020.

35Tumisah, Judge of Religious Court Palu, Class 1.A, Interview, Palu, 04 May 2020.
}

peace effort is the evidentiary process that appears during the trial when the trial is declared closed to the public. Because both parties are present, the answers will be heard between the litigants, as well as the submission of evidence before the trial. This is stated by Tumisah. ${ }^{36}$

According to Mark Frank, John Yarbrough and Paul Ekman, a confession without evidence to substantiate a testimony is in itself worthless. ${ }^{37}$ According Tumisah, ${ }^{38}$ Judge of Religious Court Palu, in essence, what was used by the panel of judges as a basis for consideration in deciding cases at the Palu Religious Court were the Qur'an, Hadith, applicable laws, Compilation of Islamic Law (KHI).

However, in addition to the considerations mentioned above, which are also used by the judge to decide a lawsuit for divorce is the opinion of the the founders of School of Islamic Laws. In addition, the judge has its own authority to explore the values that live in society.

For example, in a divorce case where the husband has left his place of residence for a long time and his residence and existence are not known, the judge refers to the opinions of the Sunni school of Islamic law. For example, the Maliki and Hambali schools are of

\footnotetext{
${ }^{36}$ Tumisah, Judge of Religious Court Palu, Class 1.A, Interview, Palu, 04 May 2020.

${ }^{37}$ Eddy O.S. Hiariej, Teori dan Pembuktian Hukum Pembuktian, (Jakarta: Erlangga, 2012), 112.

${ }^{38}$ Muwafiqoh, Judge of Religious Court Palu, Class 1.A, Interview, Palu, 22 June 2020.
} 
the opinion that judicial divorce because the husband's residence is not known is allowed, if the husband's absence lasts for a long time, even though the husband leaves his property to his wife to make a living. However, they disagreed about the limit of time. The Hanbali School specifies a time of six months, while the Maliki School specifies a year. ${ }^{39}$

Then, the next process is, according to Tumisah, ${ }^{40}$ the conclusion of what both parties and witnesses have submitted based on the conclusion stages. After this process, then enter the next stage, namely the assembly meeting. This is where the second process enters, namely making decision.

The case for talaq divorce talak or judicial divorce is discussed in Article 19 of Government Regulation Number 9 of 1975 and Article 116 of the Compilation of Islamic Law. In Article 116 of the Compilation, it is stated that divorce can occur due to the following reasons or reasons:

a) One of the parties commits adultery or becomes a drunkard, a prostitute, a gambler and others who are difficult to cure;

b) One party leaves the other party for two consecutive years without the consent of the other party and without valid reasons or for other reasons beyond their capabilities;

${ }^{39}$ Harry Kurniawan dan Maisuriati "Dasar Pertimbangan Hakim Dalam Putusan Perkara Cerai Gugat Suami Mafqud" Al-Murshalah 3, No.1 (Januari-Juni, 2017), 12.

${ }^{40}$ Tumisah, Judge of Religious Court Palu, Class 1.A, Interview, Palu, 04 May 2020. c) One of the parties is sentenced to 5 (five) years imprisonment or a heavier sentence after the marriage takes place

d) One party commits cruelty or serious persecution that endangers the other;

e) One of the parties has a disability or illness resulting in not being able to carry out the obligations as husband or wife;

f) There are continuous quarrels and fights Between husband and wife, and there is no hope of living in harmony again in the household;

g) Husband violates divorce stipulation (taklik);

h) Religious conversion or apostasy which causes disharmony in the household.

Judges use a legal basis in deciding a case for divorce and will look at the reasons put forward by the plaintiff, whether these reasons can be proven or not. Then, the judge can determine what article can fulfill these reasons. ${ }^{41}$

So, the basis of consideration is the fact that occurs in the trial. A judge will see the case, whether or not the reasons for divorce are proven, such as continuous conflict in the household. If it is proven, Article 19 letter (f) Government Regulation Number 9 of 1975 states divorce can occur if continuous disputes occur between husband and wife, and there is no hope of living in harmony again in the household.

41Tumisah, Judge of Religious Court Palu, Class 1.A, Interview, Palu, 04 May 2020.

e-ISSN: $2715-4580$ p-ISSN: 2715-8268 


\subsection{Analysis of Legal Certainty, Justice and Benefit}

Based on the results of the research, it was concluded that the judges' considerations in dealing with a lawsuit for divorce at the Palu Religious Court Class 1.A, confirmed Gustav Radbruch's theory which states that there are three objectives of law, namely legal certainty, legal justice, and legal benefit.

\section{Legal Certainty}

As stated in Law Number 1 of 1974 concerning Marriage, marriage can form a happy and eternal family based on Almighty God. In Islamic law, marriage is called a strong agreement "mitsaqon ghaliza", as stated in the Quran Chapter al-Nisa (4): 21.

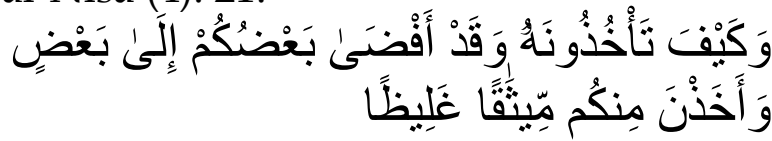

"And how could you take it back after having enjoyed each other intimately and she has taken from you a firm commitment?"

So that it is imperative between husband and wife to maintain harmony and harmony in their household.

According to Article 38 of the Marriage Law, there are three things that can break the marriage bond either due to death, divorce and a judge's decision.

The law provides choices for the judges to determine the reasons and legal basis for making decisions based on the written or unwritten laws. For example, Law Number 7 of 1989 as amended by Law Number 3 of 2006 and Law -Law Number 50 of 2009 concerning Religious Courts.
The reasons for divorce have been stated in Article 19 of Government Regulation Number 9 of 1975 in conjunction with Article 116 of the Compilation of Islamic Law.

\section{Legal Justice}

In fact, the concept of a decision that contains justice is difficult to measure for the disputing parties.It is possible that fairness for one party is not necessarily felt by other parties. Therefore, the judges have a duty to uphold justice. ${ }^{42}$

This is in accordance with the head of the verdict which reads: "For Justice Based on the One God". In terms of the implementation of the judge's decision that reflects fairness, the author analyzes one of the judges' decisions at the Palu Religious Court Class 1.A, decision Number 452 / Pdt.G / 2019 / PA.Pal regarding the case of judicial divorce on the reason that the defendant has a relationship with another woman, in which the panel of judges granted the plaintiff's claim, in order that the defendant divorce his wife.

The legal analysis shows that the verdict in this case reflects the element of justice because the panel of judges has granted the Plaintiff's claim, and there is also no hope of getting back together because both of them do not care about each other. Even the plaintiff has expressed the determination to divorce the defendant, and the defendant also

\footnotetext{
${ }^{42}$ Yohanes Suhardin, Fenomena Mengabaikan Keadilan dalam Penegakan Hukum, Jurnal Mimbar Hukum, Vol. 21 No. 2, Juni, (Yogyakarta: FH UGM, 2009), 350.
}

e-ISSN: 2715-4580 p-ISSN: 2715-8268 
has no objection to be divorced from the plaintiff. The panel of judges has implemented the conformity between the existing regulations and the judge's decision, and this judge's decision is in accordance with justice.

In Islamic legal philosophy, the concept of justice is formulated in the maqashid al-syari'ah, that law based on justice is determined by maslahat (benefit) which is divided into three, namely dharuriyyat, hajiyyat, and tahsiniyyat. This indicates that Islam is very concerned with the issue of justice. The conception of justice will continue to develop in line with social development. ${ }^{43}$

\section{Legal Utility}

The judge's decision will reflect benefits, when the judge does not only apply the law textually and only pursues justice, ${ }^{44}$ but also leads to benefits for the interests of the litigant and the public in general. This means that in applying the law, the judge should consider the final result, whether the judge's decision benefits to all parties. Judges are expected to apply existing laws and laws based on their objectives or benefits for those in court and the community.

Considering that the judge's decision is a law, the judge must maintain balance in society by restoring

${ }^{43}$ Mahir Amin, Konsep Keadilan dalam Perspektif Filsafat Hukum Islam, AL-DAULAH: Jurnal Hukum Dan Perundangan Islam Volume 4, Nomor 2, Oktober 2014; ISSN 2089-0109.

${ }^{44}$ Fence M. Wantu, Mewujudkan Kepastian Hukum, Keadilan dan Kemanfaatan dalam Putusan Hakim di Peradilan Perdata, Universitas Negeri Gorontalo: Jurnal Dinamika Hukum, Volume 12, No.3 (September 2012), 485. the social order to its original state (restitutio in integrum). The public really hopes that the settlement of cases through the courts will bring benefits to life in society. At least, the judge's decision can restore the balance of the social order. This means that the guilty party is given sanctions, while the injured party will receive compensation or get what is due to him.

To find out the form of the judge's decision that reflects the benefits, it is necessary to conduct an analysis of the implementation of the verdict at the Palu Religious Court Number 452/Pdt.G/ 2019/PA.Pal regarding the judicial divorce case:

There is a case in which Ariyenni (Plaintiff) and Iswan (Defendant) are a married couple. In this marriage, he already has two children. Then the husband and wife got into conflict which led to divorce. The Judges of the Palu Religious Court Class 1.A provide legal considerations which are basically as follows:

Whereas the plaintiff with its evidences has succeeded in proving the argument for his lawsuit which is based on Article 19 letter f of Government Regulation Number 9 of 1975, and therefore the plaintiff's demand that the marriage of the plaintiff and defendant be declared broken because the divorce can be granted entirely. Declaring that the marriage between both was broken up because of divorce with all its legal consequences.

The legal analysis shows that the decision of the panel of judges examining this case has met benefits, because it is in 
accordance with the criteria of benefit, namely that it has provided happiness and satisfaction to the parties in the case, and it also has resolved a conflict for the parties, build the good relationship between the disputing parties, and it has created a balance in society.

The benefit in this decision can be seen from the wishes of each party, both the plaintiff and the defendant, who are no longer able to maintain the marriage, because disputes and quarrels often arise, so that it is very difficult to be reunited in a marriage bond.

Gustav Radbruch said that a good law is when the law contains the values of justice, legal certainty and benefit. Even though these three values are basic legal values, each value has different demands from one another, so that all three have the potential to conflict with each other and cause tension between the three values. ${ }^{45}$

\section{Conclusions}

It can be concluded that the basis for the judge's consideration in deciding a lawsuit for divorce at the Palu Religious Court Class 1.A are two, written and unwritten law. The written law includes the Qur'an, Hadith, Law, and Compilation of Islamic Law, while the unwritten law comprises customs and values that live in society. The other judge's consideration in deciding this case is the fact that there are continuous disputes and quarrels between husband and wife, which lead to separation of

\footnotetext{
45Theo Huijbers, Filsafat Hukum dalam Lintasan Sejarah, (Yogyakarta: Kanisius, 1993), 161.
}

residence, and it is no longer possible to live in harmony in the household.

\section{REFERENCES}

Abdurrahman, Kompilasi Hukum Islam di Indonesia Edisi 1, Jakarta: Akademika Pressindo, 1995.

al-Asqalani, Al-Imam Abu fadl Ahmad bin Ali bin Hajar, Buluqul Maram min Adillatit al-Ahkam. BairutLibnan: 1410 H./1995 M.

Al-Azka, Ihdal Umam, "Fenomena Cerai Gugat: Kajian Terhadap Alasan Pengajuan dan Sikap Hukum Hakim dalam Memutuskan Perkara di Pengadilan Agama Yogyakarta", Tesis tidak diterbitkan. Yogyakarta: UIN Sunan Kalijaga, 2017.

Ali, H. Zainuddin, Hukum Perdata Islam di Indonesia, Jakarta: Sinar Grafika, 2009.

Amin, Mahir, Konsep Keadilan dalam Perspektif Filsafat Hukum Islam, AL-DAULAH: Jurnal Hukum Dan Perundangan Islam Volume 4, Nomor 2, Oktober 2014; ISSN 2089-0109.

Anonymous, Sudikno Mertokusumo, Memahami Kepastian (dalam) Hukum,

(https://ngobrolinhukum.com), Maret 2020.

Anshary, Hukum Perkawinan di Indonesia, Yogyakarta: Pustaka Pelajar, 2015.

Apeldorn, L.J. van, Inleiding tot de Sardis van het Nederlandse Recht, diterjemahkan oleh Oetarid Sadino, Pengantar Ilmu Hukum, Jakarta: pradnya Paramita, 2000. 
Arifin, Imron, ed., Penelitian Kualitatif dalam Ilmu-ilmu Sosial dan Keagamaan, Malang:

Kalimasahada Press, 1996.

Arikunto, Suharsimi, Prosedur Penelitian Suatu Pendekatan Praktik, Jakarta: PT. Rineka Cipta.

Arizona, Yance, Apa itu Kepastian Hukum ?, (https://yancearizona.net), Maret 2020.

Arto, H.A. Mukti, Praktek Perkara Perdata Pada Pengadilan Agama, Yokyakarta: Pustaka Pelajar, 2007.

Badriyah, Siti Malikhatun, Sistem Penemuan Hukum Oleh Hakim dalam Masyarakat Prismatik, Jakarta: Sinar Grafika, 2016.

Basyir, Ahamd Azhar, Keluarga Sakinah Keluarga Surgawi, Yogyakarta: Titin Ilahi Press, 1994. Hukum Perkawinan Islam,

Yogyakarta: UII Pres, 2000.

Corbin, Anselm Strauss \& Juliet, "Dasardasar Penelitian Kualitatif, Prosedur, Teknik, dan Teori Grounded," dalam Basics of Qualitative Research: Graunded Theory Procedures and Techniques, ed. M. Djunaidi Ghony, Surabaya: Bina Ilmu, 1997.

Cotterrel, Derrida dalam Roger, Sociological Perspective on Law, England: Dartmounth Publishing Company and Ashgate Publishing Company, 2001.

Departeman Pendidikan Nasional, Kamus Besar Bahasa Indonesia, Cet. 7, Jakarta: Balai Pustaka: 2014.

Duyvendijk, N.E. Algra dan Van, Penerjemah J.C.T. Simorangkir, Editor H. Boerhanuddin Soetan
Batoeah, Pengantar Ilmu Hukum, Binacipta, 1991.

Dwisvimiar, Inge, "Keadilan dalam Perspektif Filsafat Ilmu Hukum", Jurnal Dinamika Hukum 11, No.3, 2011.

Ezmir, Analisis Data Metodologi Penelitian Kualitatif, Jakarta: Rajawali Pers, 2012.

Fanani, Ahmad Zaenal, Berfikir Falsafati dalam Putusan Hakim, Artikel ini pernah dimuat di Varia Peradilan No.304 Maret 2011.

FOKUSMEDIA, Tim Redaksi, Himpunan Peraturan Perundang-Undangan Tentang Kompilasi Hukum Islam, Bandung: Fokusmedia, 2005.

Harahap, M. Yahya, Kedudukan Kewenangan Dan Acara Peradilan Agama UU No. 7 Tahun 1989 Edisi Kedua, Jakarta: Sinar Garafika, 2007.

Kedudukan Kewenangan Dan Acara Pengadilan Agama, Cet. Ke-2: Jakarta: Sinar Grafika, 2003.

Harahap, Taufik Hidayat, "Fenomena Kasus Cerai Gugat (Studi Kasus di Mahkamah Syar'iyah Tapaktuan)" Al-Murshalah 1, No.2 JuliDesember, 2015.

Hiariej, Eddy O.S., Teori dan Pembuktian Hukum Pembuktian, Jakarta: Erlangga, 2012.

Hoerudin, Ahrum, Pengadilan Agama (Bahasan Tentang Pengertian, Pengajuan Perkara, dan Kewenangan Pengadilan Agama Setelah Berlakunya UndangUndang Nomor 7 Tahun 1989 Tentang Peradilan Agama), 
Bandung: PT. Aditya Bakti, 1999.

Huijbers, Theo, Filsafat Hukum dalam Lintasan Sejarah, Yogyakarta: Kanisius, 1993.

Hutasoit, Bolmer, Artikel Politik Hukum: Tujuan Hukum Menurut Gustav Radbruch, (On-line), https://bolmerhutasoit.wordpre ss.com, Maret 2020.

Iqbal, M., Rusli, R., \& Musyahidah, M. (2019). Management Strategies of Professional Zakat Funds for Mustahiq Family Welfare By Amil Zakat Body INTERNATIONAL JOURNAL OF CONTEMPORARY ISLAMIC LAW AND SOCIETY, 1(1), 39-51.

Iriani, Dewi, Pengetahuan Ilmu Hukum dan Pengenalan tentang Hukum di Indonesia, Ponorogo: CV. Senyum Indonesia, 2016.

Isnantiana, Nur Iftitah, Legal Reasoning Hakim Dalam Pengambilan Putusan Perkara di Pengadilan,Jurnal Pemikiran Islam ISLAMADINA 18, no. 2, Juni 2017.

Ivaniar, Rendy, Buku Saku Pengantar Ilmu Hukum \& Ilmu Hukum Indonesia, Malang: Sun Action Group, 2010.

Kabalmay, Husin Ang, "Keadilan Sebagai Tujuan Hukum", Jurnal Tahkim 6, No.1, 2010.

Kamil, Iskandar "Kode Etik Profesi Hakim" dalam Pedoman Peilaku Hakim (Code of Conduct), Kode Etik Hakim dan Makalah Berkaitan, Jakarta: Mahmakah Agung RI, 2006.

Kementerian Agama Republik Indonesia, Al-Qur'an dan Terjemahnya,
Bekasi: Lajnah Pentashihan Mushaf Al-Qur'an Kementerian Agama Republik Indonesia, 2013.

Kurniawan,

Aris,

https://www.gurupendidikan.c o.id/pengertian-wawancara/, Juni 2020.

Latif, Djamil, Aneka perceraian di Indonesia, Jakarta: Galia Indonesia, 1982.

Mahfud MD, Moh, Politik Hukum di Indonesia, Jakarta: Rajawali Pers, 2011.

Mahmakah Agung Republik Indonesia, Pedoman Perilaku Hakim (Code of Conduct), Kode Etik Hakim, Jakarta: Pusdiklat MA RI, 2006.

Maisuriati, dan Herry Kurniawan, "Dasar Pertimbangan Hakim Dalam Putusan Perkara Cerai Gugat Suami Mafqud" Al-Murshalah 3, No.1, Januari-Juni, 2017.

Mertokusumo, Sudikno, Penemuan Hukum, Edisi Revisi, Yogyakarta: Universitas Atma Jaya Yogyakarta, 2014.

Moleong, Lexy J., Metodologi Penelitian Kualitatif, Bandung: Remaja Rosdakarya, 2005. Metodologi Penelitian Kualitatif, Cet.XXIX, Bandung: Remaja Rosdakarya, 2005.

Muhadjir, Neong, Metodologi Penelitian, Yogyakarta: Rake Sarasin, 1994.

Muslih, I., Nurdin, N., \& Marzuki, M. (2020). Effectiveness of Marriage Services Through Information System Management (SIMKAH) at Palu City Religious Court INTERNATIONAL JOURNAL OF CONTEMPORARY ISLAMIC LAW AND SOCIETY, 2(1), 20-36.

e-ISSN: $2715-4580$ p-ISSN: 2715-8268 
Nurdin, N. (2018). Institutional Arrangements in E-Government Implementation and Use: A Case Study From Indonesian Local Government. International Journal of Electronic Government Research (IJEGR), 14(2), 44-63. https://doi.org/10.4018/ijegr.201 8040104

Nurdin, N., Stockdale, R., \& Scheepers, H. (2014a). Coordination and Cooperation in E-Government: An Indonesian Local E-Government Case The Electronic Journal of Information Systems in developing Countries, 61(3), 1-21.

Nurdin, N. (2017a). Research in Online Space: The Use of Social Media for Research Setting Jurnal Sistem Informasi (Journal of Information System), 13(1), 67-77.

Nurdin, N. (2017b). To Research Online or Not to Research Online: Using Internet-Based Research in Islamic Studies Context. Indonesian Journal of Islam and Muslim Societies, 7(1), 31-54.

Nurdin, N., \& Yusuf, K. (2020). Knowledge management lifecycle in Islamic bank: the case of syariah banks in Indonesia. International Journal of Knowledge Management Studies, 11(1), 59-80. https://doi.org/10.1504/ijkms.2020. 105073

Peraturan Pemerintah Republik Indonesia Nomor 9 Tahun 1975 Tentang Pelaksanaan UndangUndang Nomor 1 Tahun 1974 Tentang Perkawian, BAB V, Jakarta: Raja Grafindo Pers, 2002.
R. Soeparmono, Hukum Acara Perdata dan Yurisprudensi, Bandung: Mandar Maju, 2015.

Rahman, Zaeni Asyhadie dan Arif, Pengantar Ilmu Hukum, Jakarta: PT. Raja Grafindo Persada, 2014.

Rani, Tihami, dan. Sohari Sah, Fikih Munakahat Kajian Fikih Nikah Lengkap, Jakarta: Rajawali Pers, 2014.

Rifa'i, Ahmad, Penemuan Hukum oleh Hakim dalam Perspektif Hukum Progresif, Jakarta: Sinar Garafika, 2010.

Penemuan Hukum Oleh Hakim Dalam Perspektif Hukum Progresif, Jakarta: Sinar Grafika, 2011.

Risa, Yulia, dkk, "Analisis Yuridis Alasan Cerai Gugat dan Akibat Hukum Perceraian: Studi Kasus Putusan di Pengadilan Agama Kota Solok Kelas II Tahun 2014-2016", IJTIHAD: Jurnal Hukum Islam dan Pranata Sosial, Volume 32, No.2, 2016.

Rusli, R. (2017). Wahdah Islamiyyah Palu: on Contemporary Islamic Legal Issues in The Internet. Hunafa: Jurnal Studia Islamika, 14(2).

Rusli Rusli, "Hermeneutical Reading of TTalāq," HUNAFA: Jurnal Studia Islamika 12, no. 2 (2016): 209-229.

Rusli Rusli, "The Role of Family in Preventing Social Conflict in Society From Islamic Perspectives," HUNAFA: Jurnal Studia Islamika 17, no. 1 (2020): 108-122

Santoso, Yahyanto dan Lukman, Pengantar Ilmu Hukum, Yogyakarta: Trussmedia Grafika, 2014.

e-ISSN: 2715-4580 p-ISSN: 2715-8268 
Simorangkir dkk, Kamus Hukum, Cet. Ke-12: Jakarta: Sinar Grafika, 2008.

Subekti, Pokok-Pokok Hukum Perdata, Cet. XXXI: Jakarta: PT. Intermasa, 2003.

Sudirman, Antonius, Hati Nurani Hakim dan Putusannya, Bandung: PT. Citra Aditya Bakti, 2007.

Sugiyono, Metode Penelitian Bisnis, Bandung: Alfabeta, 2008.

Suhardin, Yohanes, Fenomena Mengabaikan Keadilan dalam Penegakan Hukum, Jurnal Mimbar Hukum, Vol. 21 No. 2, Juni, Yogyakarta: FH UGM, 2009.

Sukaenah Sukaenah, Rusli Rusli, and M. Taufan B, "The Effectiveness of Indonesia Supreme Court Regulation Number 1 Year 2016 Concerning Mediation of Marriage Disputes," INTERNATIONAL JOURNAL OF CONTEMPORARY ISLAMIC LAW AND SOCIETY 2, no. 1 (2020): 63-80

Susanto, Nur Agus, "Dimensi Aksiologis dari Putusan Kasus", Jurnal Yudisial 7, No.3, 2014.

Dimensi Aksiologis dari Putusan Kasus "ST" Kajian Putusan Peninjauan Kembali Nomor 97 PK/Pid.Sus/2012, Jurnal Yudisial 7, No.3 2014.

Suyuti, Wildan, Teknik Pembuatan Putusan (On-line), (https://www.ptasemarang.go.id), Maret 2020.

Syarifuddin, Amir, Hukum Perkawinan Islam di Indonesia (Antara Fiqih Munakahat dan UU Perkawinan), Jakarta: Prenada Media, 2007.
Tanya, Bernard L., dkk, Teori Hukum: Strategi Tertib Manusia Lintas Ruang dan Generasi, Yogyakarta: Genta Publishing, 2013.

Tanya, Yovita A. Mangesti \& Bernard L., Moralitas Hukum, Yogyakarta: Genta Publishing, 2014.

Undang-Undang Nomor 3 Tahun 2006 Tentang Pembaharuan Atas Undang-Undang Nomor 7 Tahun 1989 Tentang Peradilan Agama.

Undang-undang Nomor 48 Tahun 2009 tentang Kekuasaan Kehakiman.

Undang-Undang Republik Indonesia No. 1 Tahun 1974 Tentang Perkawinan, Surabaya: Arkola, t.th.

Undang-Undang Republik Indonesia No. 1 Tahun 1974 Tentang Perkawian, Bab IV Pasal 25, Jakarta: Raja Grafindo Pers, 2002.

Undang-Undang RI No. 1 Thaun 1974 Tentang Perkawinan dan Kompilasi Hukum Islam Serta Perpu Tahun 2009 Tentang Penyelenggaraan Ibadah haji, Surabaya: Kesindo Utama, 2012.

W. Friedman, Legal Theory, diterjemahkan oleh Muhammad Arifin dengan judul Teori dan Filsafat Hukum-Idealisme Filosofis dan Problematika Keadilan (Susunan II), Jakarta: Raja Grafindo Persada: 1994.

Wantu, Fence M., Mewujudkan Kepastian Hukum, Keadilan dan Kemanfaatan dalam Putusan Hakim di Peradilan Perdata, Universitas Negeri Gorontalo: Jurnal Dinamika 
Hukum, Volume 12, No.3, September 2012.

Yahanan, Muhammad Syaifuddin, Sri Tarutmiyah dan Annalisa, Hukum Perceraiaan, Jakarta: Sinar Grafika, 2014.

Yasin, "Pertimbangan Hakim dalam Memutus Perkara Cerai Gugat (Telaah Kritis Putusan Pengadilan Agama Di Wilayah Sulawesi Utara)". Disertasi Tidak Diterbitkan. Makassar: Program Pascasarjana UIN Alauddin, 2017.

Yin, Robert K., Case Study Design and Methods, Terj. M. Djauzi Mudzakir dengan judul: Studi Kasus Desain dan Metode, Cet. I, 113. 